\title{
Comparison of the Efficacy and Safety of Non-Steroidal Anti- Inflammatory Drugs and Corticosteroid Drugs for Prevention of Cystoid Macular Edema After Cataract Surgery: A Systematic Review and Network Meta-Analysis
}

Shanshan Li ( $\square$ 13236941553@163.com)

Beijing Luhe Hospital https://orcid.org/0000-0002-5905-5247

Hui-Hui Wang

Beijing Chao-Yang Hospital: Beijing Chaoyang Hospital

Da-Wei Zhang

Beijing Luhe Hospital

\section{Research Article}

Keywords: non-steroidal anti-inflammatory drugs, corticosteroid, cystoid macular edema, cataract surgery, network meta-analysis

Posted Date: November 8th, 2021

DOI: https://doi.org/10.21203/rs.3.rs-954313/v1

License: (1) This work is licensed under a Creative Commons Attribution 4.0 International License. Read Full License 


\section{Abstract \\ Introduction:}

To compare the efficacy and safety of non-steroidal anti-inflammatory drugs (NSAID), corticosteroid (CS), and a combination of both drugs to prevent cystoid macular edema (CME) after cataract surgery.

\section{Methods}

We searched Pubmed, Cochrane Library, and Embase electronic databases to assess the relevant randomized controlled trials (RCTs) up to 28 April 2021. Network meta-analysis was registered on PROSPERO (CRD42020182520).

\section{Results}

Twenty-four RCTs were included in this review. The NSAID and combination of both drugs were significantly reduced the risk of developing CME than CS alone in non-diabetics and mix population. In the ranking profiles, the combination therapy showed a significant advantage over the single drugs and was less likely to develop CME. Diclofenac was the most likely to reduce the odds of developing CME compared with bromfenac and nepafenac. Dexamethasone was the most likely to reduce the odds of developing CME compared with betamethasone and fluorometholone.

\section{Conclusion}

NSAID combination with CS has significantly reduced the risk of developing CME postoperatively than the single drug. Diclofenac was superior to bromfenac and nepafenac in preventing CME. Dexamethasone was superior to betamethasone and fluorometholone in preventing CME.

\section{Introduction}

The cataract is the leading global cause of visual impairment, and cataract surgery is one of the most commonly performed operations in the world [1]. Even though phacoemulsification has significantly decreased the incidence of complications, cystoid macular edema (CME), known as Irvine-Gass syndrome [2], is one of the most common complications after cataract surgery [3]. CME is characterized by fluid accumulation due to leakage from capillaries in the central retina [4]. CME usually occurs within 3 months after surgery, and a peak incidence at 4 to 6 weeks [5]. The previous study showed an incidence of angiographic CME in up to $30 \%$ of nondiabetics without complicated cataract surgery [6, 7]. However, diabetics have a higher risk of developing CME postoperatively in up to $56 \%$ [8]. There is a significant morbidity of CME which can lead to permanent visual impairment.

Rossetti and colleagues performed a meta-analysis in 1998 and reported anti-inflammatory treatments were effective in reducing the odds of CME postoperatively [9]. Since then, many researchers have used corticosteroid (CS) and/or non-steroidal anti-inflammatory drugs (NSAID) to prevent CME. NSAID is a kind of anti-inflammatory drugs and effective to prevent the odds of CME postoperatively [10]. Two previous pairwise metaanalyses showed that NSAID reduced the risk of developing CME [11, 12]. However, the treatment protocol of the prevention of developing CME has shown some controversy with a lack of clear evidence on a clinical decision [13]. Some recent studies recommended the use of a combination of CS and NSAID had a lower risk of developing CME than a single drug [14, 15].

This network meta-analysis (NMA) was assessed randomized controlled trials (RCTs) to compare the efficacy and safety of NSAID, CS, and combination treatments to prevent CME. We further investigate the efficacy of various NSAID and CS to prevent CME postoperatively. This review synthesized direct and indirect comparisons to summary the best available treatments.

\section{Methods}

We performed this meta-analysis by the guideline of the Preferred Reporting Items for Systematic Reviews (PRISMA) [16]. The network metaanalysis was registered on PROSPERO (CRD42020182520).

\section{Search methods}

We searched Pubmed, Cochrane Library, and Embase electronic databases to assess the relevant articles up to 28 April 2021 , by using the items: (Cataract Surgery or Cataract Extraction or Lens Implantation or Phacoemulsification) and (macular edema or edema or Irvine gass).

Additionally, two reviewers (SSL and RY) conducted the Internet-based search for eligibility independently. There were no language limitations. Discrepancies among authors were resolved by discussion. 


\section{Study selection}

We included the relevant articles that met the criteria: (1) randomized controlled trials; (2) the studies included participants underwent cataract extraction with posterior chamber intraocular lens implantations and received anti-inflammatory treatments after surgery; (3) the results of the incidence of CME or adverse events was included in the study. We excluded the relevant articles that met the exclusion criteria: the studies including participants with preoperative CME or a high risk of developing CME after cataract surgery.

\section{Data extraction and Quality Assessment}

All data were extracted by two investigators (SSL and HHW) independently. Extracted data consisted of the name of the first author, publication year, location, study sample, the age of participants, drugs of interventions, follow-up time, the incidence of macular edema, and adverse events.

The risk of bias of included articles was assessed by two authors (HHW and SSL) using the Cochrane Collaboration's Tool, assessing the following items: random sequence generation, allocation concealment, blinding of participants and personnel, blinding of outcome reporting, and other bias. For each item was scored as "low bias", "high bias", or "unclear of bias". The authors of articles that did not report important outcomes were contacted.

\section{Statistical Analysis}

\section{Methods for direct treatment comparisons}

We performed head-to-head (direct) comparisons using relative risk (RR) with $95 \%$ confidence intervals (Cls) to determine the effect sizes. $P$ statistic value was used to assess heterogeneity.

\section{Methods for indirect and mixed comparisons}

The NMA was based on a random-effects model in a frequentist framework. We reported RR with 95\% Cls for indirect and mixed comparisons [17]. We performed comparison-adjusted funnel plots to assess publication bias. The NMA ranked the treatments to provide clinical decisions using surface under the cumulative ranking (SUCRA) probabilities. We used STATA 15.1 for all data analyses (pairwise and NMA, $R$ measure, SUCRA graphs, and funnel plot).

\section{Result}

We searched PubMed, Cochrane Library, and Embase databases for relevant randomized controlled trials (RCTs). We identified 12648 studies. After records of duplicates and not relevant were removed, fifty-five full papers were assessed. Thirty-one studies were excluded because of duplicate data, incorrect comparators, and incorrect outcomes. Finally, 24 RCTs were included in this review (Fig. 1).

Baseline characteristics of included patients are summarized in table 1. Twenty-four RCTs (including 5130 patients) were published between 1997 and 2018. Seventeen trials enrolled in non-diabetic patients. Four trials included only diabetic patients. Three trials included mixed patients. The follow-up time of the studies varied from 4 weeks to 140 days. In our NMA, the NSAID included ketorolac, bromfenac, nepafenac, diclofenac, and indomethacin, the CS included prednisolone, betamethasone, fluorometholone, and dexamethasone.

Table 1 Characteristics of trials included in the network meta-analysis 


\begin{tabular}{|c|c|c|c|c|c|c|c|}
\hline Study & Location & Sample & Age & Interventions & Drugs & $\begin{array}{l}\text { Follow- } \\
\text { up }\end{array}$ & Patients \\
\hline $\begin{array}{l}\text { Almeida } \\
2008[18]\end{array}$ & Canada & $53: 53$ & $71(45-92)$ & $\begin{array}{l}\text { Steroid+NSAID } \\
\text { VS Steroid }\end{array}$ & $\begin{array}{l}\text { Prednisolone } 1 \% \\
\text { (postop) + Ketorolac } \\
0.5 \% \text { (preop + postop) } \\
\text { VS Prednisolone 1\% } \\
\text { (postop) }\end{array}$ & $4 \mathrm{~W}$ & $\begin{array}{l}\text { mix (diabetes, } \\
\text { glaucoma, } \\
\text { macular disease, } \\
\text { Pseudoexfoliation } \\
\text { syndrome, } \\
\text { hypertension) }\end{array}$ \\
\hline Asano 2008[19] & Japan & $69: 69$ & 66 & $\begin{array}{l}\text { NSAID VS } \\
\text { Steroid }\end{array}$ & $\begin{array}{l}\text { diclofenac } 0.1 \% \text { VS } \\
\text { betamethasone } 0.1 \% \\
\text { (postop) }\end{array}$ & $8 W$ & $\begin{array}{l}\text { low risk (uveitis } \\
\text { and diabetes were } \\
\text { excluded) }\end{array}$ \\
\hline Campa 2018[15] & Italy & $48: 48: 48$ & $\begin{array}{l}78.21 \pm 7.87 \\
77 \pm 5.93 \\
78.75 \pm 7.96\end{array}$ & $\begin{array}{l}\text { Steroid+ NSAID } \\
\text { VS Steroid }\end{array}$ & $\begin{array}{l}\text { nepafenac 0.1\% (preop } \\
\text { + postop) } \\
\text { + dexamethasone } 1.32 \\
\text { mg (postop) VS } \\
\text { bromfenac (preop + } \\
\text { postop) + } \\
\text { dexamethasone } 1.32 \\
\text { mg (postop) VS } \\
\text { dexamethasone } 1.32 \\
\text { mg (postop) }\end{array}$ & $5 \mathrm{~W}$ & $\begin{array}{l}\text { low risk (diabetic } \\
\text { retinopathy and } \\
\text { retinal vein } \\
\text { occlusion were } \\
\text { excluded) }\end{array}$ \\
\hline $\begin{array}{l}\text { Cervantes-Coste } \\
2009[20]\end{array}$ & Mexico & $30: 30$ & $\begin{array}{l}72.6 \pm 10.5: \\
71.2 \pm 8.8\end{array}$ & $\begin{array}{l}\text { Steroid+ NSAID } \\
\text { VS Steroid }\end{array}$ & $\begin{array}{l}\text { nepafenac 0.1\% (preop } \\
+ \text { postop) + } \\
\text { dexamethasoe (postop) } \\
\text { VS dexamethasoe } \\
\text { (postop) }\end{array}$ & $6 \mathrm{~W}$ & $\begin{array}{l}\text { mix (including } \\
\text { diabetics and } \\
\text { other patients) }\end{array}$ \\
\hline $\begin{array}{l}\text { Chatziralli } \\
\text { 2011[21] }\end{array}$ & Greece & $70: 68$ & $\begin{array}{l}74.3 \pm 7.3 \\
74.0 \pm 7.6\end{array}$ & $\begin{array}{l}\text { Steroid+ NSAID } \\
\text { VS Steroid }\end{array}$ & $\begin{array}{l}\text { ketorolac tromethamine } \\
0.5 \% \text { (preop + postop) } \\
\text { +dexamethasone 0.1\% } \\
\text { (preop + postop) VS } \\
\text { dexamethasone } 0.1 \% \\
\text { (preop + postop) }\end{array}$ & $6 \mathrm{~W}$ & $\begin{array}{l}\text { mix (diabetes, } \\
\text { glaucoma, } \\
\text { macular disease, } \\
\text { Pseudoexfoliation } \\
\text { syndrome, } \\
\text { hypertension) }\end{array}$ \\
\hline $\begin{array}{l}\text { Donnenfeld } \\
2006[22]\end{array}$ & USA & $75: 25$ & 73 & $\begin{array}{l}\text { Steroid+ NSAID } \\
\text { VS Steroid }\end{array}$ & $\begin{array}{l}\text { Prednisolone } 1 \% \\
\text { (postop) + Ketorolac } \\
0.4 \% \text { (preop + postop) } \\
\text { VS Prednisolone 1\% } \\
\text { (postop) }\end{array}$ & $12 \mathrm{~W}$ & $\begin{array}{l}\text { low risk (uveitis } \\
\text { and diabetes were } \\
\text { excluded) }\end{array}$ \\
\hline Elsawy 2013[23] & Egypt & $35: 35$ & NR & $\begin{array}{l}\text { Steroid+ NSAID } \\
\text { VS Steroid }\end{array}$ & $\begin{array}{l}\text { ketorolac tromethamine } \\
0.4 \%+\text { dexamethasone } \\
0.1 \% \text { VS } \\
\text { dexamethasone } 0.1 \% \\
\text { (postop) }\end{array}$ & $12 \mathrm{~W}$ & diabetes \\
\hline $\begin{array}{l}\text { Italian } \\
\text { Diclofenac } \\
\text { Study Group } \\
\text { 1997[24] }\end{array}$ & Italy & 121:108 & $\begin{array}{l}68.3 \pm 7.4 \\
67.5 \pm 7.7\end{array}$ & $\begin{array}{l}\text { NSAID VS } \\
\text { Steroid }\end{array}$ & $\begin{array}{l}\text { diclofenac } 0.1 \% \\
\text { (postop) VS } \\
\text { dexamethasone } 0.1 \% \\
\text { (postop) }\end{array}$ & $140 \mathrm{D}$ & $\begin{array}{l}\text { low risk (a senile } \\
\text { cataract without } \\
\text { vitreoretinal } \\
\text { pathology) }\end{array}$ \\
\hline Miyake 1999[25] & Japan & $36: 37$ & $\begin{array}{l}68.2 \pm 7.2 \rrbracket \\
69.9 \pm 8.2\end{array}$ & $\begin{array}{l}\text { NSAID VS } \\
\text { Steroid }\end{array}$ & $\begin{array}{l}\text { Diclofenac } 0.1 \% \text { VS } \\
\text { Fluometholone } 0.1 \% \\
\text { (preop + postop) }\end{array}$ & $5 \mathrm{~W}$ & glaucoma \\
\hline $\begin{array}{l}\text { Miyanaga } \\
2009[26]\end{array}$ & Japan & $25: 24: 23$ & $\begin{array}{l}74(48-86) ; \\
71(46-86) \\
70(41-83)\end{array}$ & $\begin{array}{l}\text { NSAID VS } \\
\text { Steroid+ NSAID } \\
\text { VS Steroid }\end{array}$ & $\begin{array}{l}\text { Bromfenac } 0.1 \% \text { VS } \\
\text { Betamethasone } 0.1 \% \\
\text { and Fluometholone } \\
0.1 \%+\text { Bromfenac } 0.1 \% \\
\text { VS Betamethasone } \\
0.1 \% \text { and } \\
\text { Fluometholone } 0.1 \% \\
\text { (postop) }\end{array}$ & $8 W$ & $\begin{array}{l}\text { low risk (uveitis } \\
\text { and diabetes were } \\
\text { excluded) }\end{array}$ \\
\hline Miyake 2007[27] & Japan & $25: 25$ & $\begin{array}{l}65.4 \pm 7 \\
65.8 \pm 7.1\end{array}$ & $\begin{array}{l}\text { NSAID VS } \\
\text { Steroid }\end{array}$ & $\begin{array}{l}\text { diclofenac } 0.1 \% \\
\text { (postop) VS } \\
\text { fluorometholone } 0.1 \% \\
\text { (postop) }\end{array}$ & $5 \mathrm{~W}$ & $\begin{array}{l}\text { low risk (uveitis } \\
\text { and diabetes were } \\
\text { excluded) }\end{array}$ \\
\hline Miyake 2011[28] & Japan & $28: 27$ & $\begin{array}{l}64.3 \pm 7.8 \\
65.7 \pm 12.2\end{array}$ & $\begin{array}{l}\text { NSAID VS } \\
\text { Steroid }\end{array}$ & $\begin{array}{l}\text { nepafenac } 0.1 \% \text { (preop } \\
\text { + postop) VS } \\
\text { fluorometholone } 0.1 \% \\
\text { (preop + postop) }\end{array}$ & $5 \mathrm{~W}$ & $\begin{array}{l}\text { mix (without } \\
\text { diabetes } \\
\text { retinopathy, } \\
\text { glaucoma, } \\
\text { macular disease, } \\
\text { Pseudoexfoliation } \\
\text { syndrome) }\end{array}$ \\
\hline
\end{tabular}




\begin{tabular}{|c|c|c|c|c|c|c|c|}
\hline $\begin{array}{l}\text { Moschos } \\
2012[29]\end{array}$ & Greece & $38: 41$ & $\begin{array}{l}76.68 \pm 10.72 \\
76.71 \pm 8.82\end{array}$ & $\begin{array}{l}\text { Steroid+ NSAID } \\
\text { VS Steroid }\end{array}$ & $\begin{array}{l}\text { Dexamethasone } 0.1 \% \\
\text { (postop) + Diclofenac } \\
0.1 \% \text { (preop + postop) } \\
\text { VS Dexamethasone } \\
0.1 \% \text { (postop) }\end{array}$ & $4 \mathrm{~W}$ & $\begin{array}{l}\text { low risk (uveitis } \\
\text { and diabetes were } \\
\text { excluded) }\end{array}$ \\
\hline $\begin{array}{l}\text { Pollack } \\
2017[30]\end{array}$ & multicentre & $87: 88$ & $\begin{array}{l}68.1 \pm 8.6 \\
69.4 \pm 7.6\end{array}$ & $\begin{array}{l}\text { Steroid+ NSAID } \\
\text { VS Steroid }\end{array}$ & $\begin{array}{l}\text { nepafenac } 0.1 \% \text { (preop } \\
+ \text { postop) + } \\
\text { dexamethasone } 0.1 \% \\
\text { (postop) VS } \\
\text { dexamethasone } 0.1 \% \\
\text { (postop) }\end{array}$ & $3 \mathrm{M}$ & diabetes \\
\hline $\begin{array}{l}\text { Rossetti } \\
\text { 1996[31] }\end{array}$ & Italy & $42: 46$ & $\begin{array}{l}74.2 \pm 8.8 \\
72.9 \pm 9.4\end{array}$ & $\begin{array}{l}\text { Steroid+ NSAID } \\
\text { VS Steroid }\end{array}$ & $\begin{array}{l}\text { diclofenac sodium } \\
\text { (preop + postop) + } \\
\text { dexamethasone } \\
\text { (postop) VS } \\
\text { dexamethasone } \\
\text { (postop) }\end{array}$ & $6 \mathrm{M}$ & $\begin{array}{l}\text { low risk } \\
\text { (maculopathy } \\
\text { and diabetes were } \\
\text { excluded) }\end{array}$ \\
\hline Singh 2012[32] & USA & $125: 126$ & $\begin{array}{l}66.6 \pm 9.3 \\
66.4 \pm 9.7\end{array}$ & $\begin{array}{l}\text { Steroid+ NSAID } \\
\text { VS Steroid }\end{array}$ & $\begin{array}{l}\text { nepafenac } 1 \% \text { (preop + } \\
\text { postop) + prednisolone } \\
\text { acetate (postop) VS } \\
\text { prednisolone acetate } \\
\text { (postop) }\end{array}$ & $3 \mathrm{M}$ & diabetes \\
\hline Singh 2017[33] & multicentre & $587: 593$ & $\begin{array}{l}67.2 \pm 8.5 \\
67.4 \pm 8.3\end{array}$ & $\begin{array}{l}\text { Steroid+ NSAID } \\
\text { VS Steroid }\end{array}$ & $\begin{array}{l}\text { nepafenac } 0.3 \% \text { (preop } \\
+ \\
\text { postop) + prednisolone } \\
\text { acetate (postop) VS } \\
\text { prednisolone acetate } \\
\text { (postop) }\end{array}$ & $3 \mathrm{M}$ & diabetes \\
\hline Ticly 2014[34] & Brazil & $37: 44$ & $\begin{array}{l}67.1 \pm 10.8 \\
66.1 \pm 8.7\end{array}$ & $\begin{array}{l}\text { Steroid+ NSAID } \\
\text { VS Steroid }\end{array}$ & $\begin{array}{l}\text { Prednisolone } 1 \%+ \\
\text { Ketorolac } 0.4 \% \text { VS } \\
\text { Prednisolone } 1 \% \text { (preop } \\
\text { + postop) }\end{array}$ & $5 \mathrm{~W}$ & $\begin{array}{l}\text { low risk (uveitis } \\
\text { and diabetes were } \\
\text { excluded) }\end{array}$ \\
\hline $\begin{array}{l}\text { Tzelikis } \\
2018[35]\end{array}$ & Brazil & $112: 112$ & $68.32 \pm 9.08$ & $\begin{array}{l}\text { Steroid+ NSAID } \\
\text { VS Steroid }\end{array}$ & $\begin{array}{l}\text { nepafenac } 0.3 \%+ \\
\text { prednisolone } 1.0 \% \text { VS } \\
\text { prednisolone } 1.0 \% \\
\text { (preop + postop) }\end{array}$ & $12 \mathrm{~W}$ & $\begin{array}{l}\text { low risk (uveitis } \\
\text { and diabetes were } \\
\text { excluded) }\end{array}$ \\
\hline Wang 2013[36] & China & $83: 84$ & $73.37 \pm 9.17$ & $\begin{array}{l}\text { Steroid+ NSAID } \\
\text { VS Steroid }\end{array}$ & $\begin{array}{l}\text { Prednisolone } 15 \mathrm{mg}+ \\
\text { Bromfenac } 0.1 \% \mathrm{VS} \\
\text { Prednisolone } 15 \mathrm{mg}+ \\
\text { Fluometholone } 0.1 \% \text { or } \\
\text { Dexamethasone } 0.1 \% \\
\text { (postop) }\end{array}$ & $8 W$ & $\begin{array}{l}\text { age-related } \\
\text { cataract without } \\
\text { any other ocular } \\
\text { diseases }\end{array}$ \\
\hline $\begin{array}{l}\text { Wielders } \\
2018[14]\end{array}$ & European & $270: 265: 265$ & $\begin{array}{l}69.70 \pm 8.94 \rrbracket \\
71.23 \pm 8.73 \rrbracket \\
70.41 \pm 8.91\end{array}$ & $\begin{array}{l}\text { NSAID VS } \\
\text { Steroid VS } \\
\text { NSAID+Steroid }\end{array}$ & $\begin{array}{l}\text { bromfenac } 0.09 \% \text { VS } \\
\text { dexamethasone } 0.1 \% \\
\text { VS dexamethasone } \\
0.1 \%+\text { bromfenac } \\
0.09 \% \text { (preop + postop) }\end{array}$ & $12 \mathrm{~W}$ & nondiabetics \\
\hline $\begin{array}{l}\text { Wittpenn } \\
\text { 2008[37] }\end{array}$ & USA & $268: 278$ & $70: 70$ & $\begin{array}{l}\text { Steroid+ NSAID } \\
\text { VS Steroid }\end{array}$ & $\begin{array}{l}\text { ketorolac } 0.4 \% \text { (preop + } \\
\text { postop) }+ \text { prednisolone } \\
\text { acetate } 1 \% \text { (postop) VS } \\
\text { prednisolone acetate } \\
1 \% \text { (postop) }\end{array}$ & $4 \mathrm{~W}$ & $\begin{array}{l}\text { low risk (without } \\
\text { maculopathy and } \\
\text { retinal-vascular } \\
\text { anomalies) }\end{array}$ \\
\hline Yavas 2007[38] & Turkey & $121: 58$ & $64 ; 65$ & $\begin{array}{l}\text { Steroid+ NSAID } \\
\text { VS Steroid }\end{array}$ & $\begin{array}{l}\text { Prednisolone 1\% } \\
\text { (postop) + } \\
\text { Indomethacin } 0.1 \% \\
\text { (postop or preop + } \\
\text { postop) VS } \\
\text { Prednisolone 1\% } \\
\text { (postop) }\end{array}$ & $4 \mathrm{~W}$ & $\begin{array}{l}\text { low risk } \\
\text { (hypertension and } \\
\text { diabetes were } \\
\text { excluded) }\end{array}$ \\
\hline Zaczek 2014[39] & Sweden & $75: 77$ & $\begin{array}{l}70.4 \pm 7.4 \\
68.3 \pm 7.5\end{array}$ & $\begin{array}{l}\text { Steroid+ NSAID } \\
\text { VS Steroid }\end{array}$ & $\begin{array}{l}\text { nepafenac } 0.1 \%+ \\
\text { dexamethasone } 0.1 \% \\
\text { (preop + postop) VS } \\
\text { dexamethasone } 0.1 \% \\
\text { (postop) }\end{array}$ & $4 \mathrm{~W}$ & $\begin{array}{l}\text { low risk (uveitis } \\
\text { and diabetes were } \\
\text { excluded) }\end{array}$ \\
\hline
\end{tabular}

W: Weeks, M: Months, D. days, NSAID: inflammatory drugs

Quality of evidence 
We included RCTs in this NMA. There was an assessment of the risk of bias within RCTs in Figure 2. The majority of studies were marked as "unclear" for selection bias because they did not report sufficient information associated to judge selection bias. Eleven RCTs were open-label nonmasked studies and marked as "high risk" for performance bias. Eight RCTs were marked as "low risk" for performance bias. We judged nine studies as "high risk" and ten studies as "low risk" in terms of detection bias. Two studies were assigned a "high risk" of bias for attrition bias. Only one trial was marked as a "high risk" of bias for incomplete data. The quality of evidence of included RCTs was low to moderate (Fig. 2).

\section{Pairwise and network meta-analyses}

This NMA included 24 relevant studies, which compared the incidence of CME with NSAID, CS, and combination therapy after cataract surgery. The main findings of pairwise and network meta-analyses were presented in table 2 . Sixteen studies reported the incidence of CME in non-diabetics. The results of pairwise and network meta-analysis showed NSAID and combination of both drugs were significantly superior to the CS alone in non-diabetics (RR 0.33, 95\% Cl 0.23 to 0.48 ; RR 0.24, 95\% Cl 0.14 to $0.40 ; \mathrm{RR} 0.23,95 \% \mathrm{Cl} 0.14$ to 0.37 ; RR $0.19,95 \% \mathrm{Cl} 0.11$ to 0.33 ). There were only four studies compared to CS with combination therapy in terms of the incidence of CME in diabetics. The result of pairwise comparisons showed combination therapy significantly reduced the risk of developing $\mathrm{CME}$ after cataract surgery (RR $0.25,95 \% \mathrm{Cl} 0.17$ to 0.36 ). Twenty-four studies including diabetics and non-diabetics (mixed populations) reported NSAID and combination therapy significantly reduced the risk of developing CME after cataract surgery than CS in both pairwise and network meta-analysis ( $\mathrm{RR} 0.30,95 \% \mathrm{Cl} 0.22$ to 0.43 ; RR $0.34,95 \% \mathrm{Cl}$ 0.27 to 0.41 ; RR $0.2095 \% \mathrm{Cl} 0.12$ to $0.34 ; \mathrm{RR} 0.21,95 \% \mathrm{Cl} 0.15$ to 0.30 ). There were six studies reported the results of adverse events, which included mild pain, dry eyes, keratitis, and posterior vitreous detachment. The result of pairwise comparisons showed that the combination of NSAID and CS significantly reduced the risk of developing adverse events than CS (RR $0.77,95 \% \mathrm{Cl} 0.63,0.94$ ).

Table 2 Summary of main findings of pairwise and network meta-analyses

\begin{tabular}{|c|c|c|c|c|c|}
\hline \multirow[t]{2}{*}{ Parameters } & \multicolumn{4}{|c|}{ Direct pairwise meta-analysis } & \multirow{2}{*}{$\begin{array}{l}\text { Network meta-analysis } \\
\text { RR }(95 \% \mathrm{Cl})\end{array}$} \\
\hline & No. of samples & RR (95\% Cl) & $P$ & Heterogeneity $1^{2}$ & \\
\hline \multicolumn{6}{|c|}{ CME with Non-diabetics } \\
\hline NSAID VS CS & 1077 & $0.33(0.23,0.48)$ & 0.528 & $0.0 \%$ & $0.24(0.14,0.40)$ \\
\hline NSAID VS NSAID+CS & 584 & $1.81(0.68,4.83)$ & - & - & $1.25(0.62,2.55)$ \\
\hline NSAID+CS VS CS & 2295 & $0.23(0.14,0.37)$ & 0.913 & $0.0 \%$ & $0.19(0.11,0.33)$ \\
\hline \multicolumn{6}{|l|}{ CME with Diabetics } \\
\hline NSAID+CS VS CS & 1692 & $0.25(0.17,0.36)$ & 0.957 & $0.0 \%$ & - \\
\hline \multicolumn{6}{|c|}{ CME with Mixed Populations } \\
\hline NSAID VS CS & 1132 & $0.30(0.22,0.43)$ & 0.455 & $0.0 \%$ & $0.20(0.12,0.34)$ \\
\hline NSAID VS NSAID+CS & 584 & $1.81(0.68,4.83)$ & - & - & $0.98(0.55,1.74)$ \\
\hline NSAID+CS VS CS & 4968 & $0.34(0.27,0.41)$ & 0.549 & $0.0 \%$ & $0.21(0.15,0.30)$ \\
\hline
\end{tabular}

Adverse Events

\begin{tabular}{|c|c|c|c|c|c|}
\hline NSAID VS CS & 539 & $0.87(0.71,1.06)$ & - & - & $0.89(0.65,1.22)$ \\
\hline NSAID VS NSAID+CS & 535 & $1.20(0.95,1.50)$ & - & - & $1.15(0.85,1.57)$ \\
\hline NSAID+CS VS CS & 2760 & $0.77(0.63,0.94)$ & 0.72 & $0.0 \%$ & $0.77(0.47,1.27)$ \\
\hline
\end{tabular}

$C S$ : corticosteroid, NSAID: non-steroidal anti-inflammatory drugs, $C l$ : confidence interval, $C M E$ : cystoid macular edema, $R R$ : relative risk

\section{Rank probabilities}

The SUCRA ranking profiles of comparable treatments (NSAID, CS, a combination of both drugs) in non-diabetics and mixed populations. The treatment with the largest cumulative was more likely to develop CME after cataract surgery. The combination therapy showed a significant advantage over the single drugs and the less likely to develop CME (Fig. 3).

\section{Network meta-analysis of the efficacy of various NSAID and CS}


Network plot (Fig. 4. a), network meta-analysis (Fig. 4. b), and SUCRA ranking (Fig. 4. c) were assessed in terms of the incidence of CME. The Figure 4-a showed a network plot of comparisons on different outcomes of treatment incidence of CME after cataract surgery. The Figure 4-b showed the results of pooled estimates of the network meta-analysis. Diclofenac was significantly reduced the risk of developing CME than betamethasone (RR $0.32,95 \% \mathrm{Cl} 0.19$ to 0.54 ). Bromfenac was significantly reduced the risk of developing CME than dexamethasone and fluorometholone (RR 2.11, 95\% Cl 1.07 to 4.19; RR 6.17, 95\% Cl 1.15 to 33.1). Diclofenac and nepafenac showed a significant advantage over the fluorometholone (RR 7.78, 95\% Cl 2.50 to 24.83 ; RR $0.18,95 \% \mathrm{Cl} 0.07$ to 0.44 ). The Figure 4-c showed the results of the SUCRA score of each treatment. In terms of efficacy of NSAIDs, diclofenac was the most likely to reduce the odds of developing CME compared with bromfenac and nepafenac. In terms of efficacy of CS, dexamethasone was the most likely to reduce the odds of developing CME compared with betamethasone and fluorometholone.

\section{Funnel plots}

The funnel plots for the odds of developing CME after cataract surgery were presented in Figure 5. The comparison-funnel plots were symmetrical and did not reveal any obvious publication bias.

\section{Inconsistency assessment}

The results of the inconsistency test were shown in figure 6. For direct and indirect estimates, the results of the loop included 0 according to the three forest plots. Therefore, the reports of inconsistency assessment were robust.

\section{Rank probabilities}

Fig. 3 showed SUCRA ranking profiles of comparable treatments (NSAID, CS, a combination of both drugs) in non-diabetics and mixed populations. The treatment with the largest cumulative was more likely to develop CME after cataract surgery. The combination therapy showed a significant advantage over the single drugs and the less likely to develop CME.

\section{Network meta-analysis of the efficacy of various NSAID and CS}

Network plot (Fig. 4a), network meta-analysis (Fig. 4b), and SUCRA ranking (Fig. 4c) were assessed in terms of the incidence of CME. Fig. 4a showed a network plot of comparisons on different outcomes of treatment incidence of CME after cataract surgery. Fig. $4 \mathrm{~b}$ showed the results of pooled estimates of the network meta-analysis. Diclofenac was significantly reduced the risk of developing CME than betamethasone (RR 0.32 , $95 \% \mathrm{CI} 0.19$ to 0.54 ). Bromfenac was significantly reduced the risk of developing $\mathrm{CME}$ than dexamethasone and fluorometholone (RR $2.11,95 \% \mathrm{Cl}$ 1.07 to 4.19; RR 6.17, 95\% Cl 1.15 to 33.1). Diclofenac and nepafenac showed a significant advantage over the fluorometholone (RR $7.78,95 \% \mathrm{Cl}$ 2.50 to 24.83 ; RR $0.18,95 \% \mathrm{Cl} 0.07$ to 0.44 ). Fig. 4c showed the results of the SUCRA score of each treatment. In terms of efficacy of NSAIDs, diclofenac was the most likely to reduce the odds of developing CME compared with bromfenac and nepafenac. In terms of efficacy of $\mathrm{CS}$, dexamethasone was the most likely to reduce the odds of developing CME compared with betamethasone and fluorometholone.

\section{Funnel plots}

The funnel plots for the odds of developing CME after cataract surgery were presented in fig. 5. The comparison-funnel plots were symmetrical and did not reveal any obvious publication bias.

\section{Inconsistency assessment}

The results of the inconsistency test were shown in fig. 6 . For direct and indirect estimates, the results of the loop included 0 according to the three forest plots. Therefore, the reports of inconsistency assessment were robust.

\section{Discussion}

This systematic review and network meta-analysis aimed to compare the efficacy and safety of NSAID, CS, and combination of both drugs to prevent CME after uncomplicated cataract surgery in non-diabetics, diabetics, and mixed population without CME preoperatively. We also investigate the efficacy of various NSAID and CS to prevent CME postoperatively. We found that NSAID combination with CS was significantly reduced the risk of developing CME postoperatively than the single drug. A combination of NSAID and CS were less likely to develop adverse events than CS alone. In terms of the efficacy of various NSAID, diclofenac was superior to bromfenac and nepafenac in preventing CME. In terms of the efficacy of various CS, dexamethasone was superior to betamethasone and fluorometholone in preventing CME.

The results were concordant with the findings of a recent systematic review by Laursen and his colleagues, reporting that combination treatments were better than CS alone at preventing CME [40]. However, this systematic review included only diabetics and did not investigate the effects of NSAID versus CS alone and a combination of NSAID and CS. A European multicenter trial in 2018 compared the efficacy of topical NSAID, CS, and a combination of both drugs, and demonstrated that a combination of NSAID and CS reduced the risk of developing CME than a single drug in 
nondiabetics [14]. However, the results of the trials have shown inconsistent conclusions. Some studies showed NSAID had any benefit over CS alone in the prevention of CME postoperatively $[28,36]$. We compared the efficacy of various NSAID and CS to prevent CME postoperatively. We found diclofenac was superior to other NSAID and CS in preventing CME. A current systematic review also showed the diclofenac was better efficacy than other NSAID for the treatment of anterior chamber inflammation after cataract surgery [41]. However, this review only compared the efficacy of various NSAID and did not investigate the effects of NSAID versus various CS in the prevention of developing CME. We also found that Dexamethasone was superior to betamethasone and fluorometholone in preventing CME. Dexamethasone was shown to reduce both vascular permeability and leukocyte aggregation [42].

There were some limitations to this study. First, CME usually occurs within 3 months after surgery, and a peak incidence at 4 to 6 weeks [5]. The duration of follow-up time in this study is up 4 weeks to 16 weeks. Second, in our NMA, three trials using the diagnose CME on fluorescein angiography in non-diabetics (Miyake 1999; Tickly 2014; Yavas 2007). Other trials used Optical Coherence Tomography to defect CME. It was proved that the incidence of developing CME was much higher using the method of fluorescein angiography (Miyake 1999; Tickly 2014; Yavas 2007). Third, only seven RCTs were comparing the efficacy of different kinds of NSAID and CS to prevent CME postoperatively, which may limit the power in our NMA.

\section{Conclusion}

NSAID combination with CS has significantly reduced the risk of developing CME postoperatively than the single drug in non-diabetics, diabetics, and mixed populations without CME preoperatively after uncomplicated cataract surgery. A combination of both drugs was less likely to develop adverse events than CS alone. Diclofenac was superior to bromfenac and nepafenac in preventing CME. Dexamethasone was superior to betamethasone and fluorometholone in preventing CME. A combination of diclofenac and dexamethasone to prevent CME might be the preferable treatments.

\section{Declarations}

Funding This work was supported by the National Natural Science Foundation of China under Grant numbers [81870686]).

Conflicts of interests All authors declare they have no conflict of interests to declare that are relevant to the content of this article.

Availability of data and material All data are fully available without restriction.

Financial interests All authors have no relevant financial or non-financial interests to disclose.

Ethics approval This is a systematic review and network Meta-Analysis study. The data were based on previously published studies. The Beijing Friendship Hospital affiliated to Capital Medical University of Research Ethics Committee has confirmed that no ethical approval is required.

Consent to participants All analyses were based on previously published studies and therefore no patient consent is required.

Consent to publish All analyses were based on previously published studies and therefore no consent to publish is required.

\section{References}

1. Pascolini D, Mariotti SP (2012) Global estimates of visual impairment: 2010. Br J Ophthalmol 96(5):614-618

2. Irvine SR (1953) A newly defined vitreous syndrome following cataract surgery. Am J Ophthalmol 36(5):599-619

3. Chu CJ, Johnston RL, Buscombe C et al (2016) Risk Factors and Incidence of Macular Edema after Cataract Surgery: A Database Study of 81984 Eyes. Ophthalmology 123(2):316-323

4. Lim LL, Morrison JL, Constantinou M et al (2016) Diabetic Macular Edema at the time of Cataract Surgery trial: a prospective, randomized clinical trial of intravitreous bevacizumab versus triamcinolone in patients with diabetic macular oedema at the time of cataract surgery preliminary 6 month results. Clin Exp Ophthalmol 44(4):233-242

5. Yonekawa Y, Kim IK (2012) Pseudophakic cystoid macular edema. Curr Opin Ophthalmol 23(1):26-32

6. Gass JD, Norton EW (1969) Follow-up study of cystoid macular edema following cataract extraction. Trans Am Acad Ophthalmol Otolaryngol 73(4):665-682

7. Wright PL, Wilkinson CP, Balyeat HD et al (1988) Angiographic cystoid macular edema after posterior chamber lens implantation. Arch Ophthalmol 106(6):740-744

8. Dowler JG, Sehmi KS, Hykin PG et al (1999) The natural history of macular edema after cataract surgery in diabetes. Ophthalmology 106(4):663-668 
9. Rossetti L, Chaudhuri J, Dickersin K (1998) Medical prophylaxis and treatment of cystoid macular edema after cataract surgery. The results of a meta-analysis. Ophthalmology 105(3):397-405

10. Alnagdy AA, Abouelkheir HY, El-Khouly SE et al (2018) Impact of topical nonsteroidal anti-inflammatory drugs in prevention of macular edema following cataract surgery in diabetic patients. Int J Ophthalmol 11(4):616-622

11. Kim SJ, Jampel H (2016) Prevention of Cystoid Macular Edema After Cataract Surgery in Non-Diabetic and Diabetic Patients: A Systematic Review and Meta-Analysis. Am J Ophthalmol 161:221-222

12. Lim BX, Lim CH, Lim DK et al (2016) Prophylactic non-steroidal anti-inflammatory drugs for the prevention of macular oedema after cataract surgery. Cochrane Database Syst Rev 11:CD006683

13. Kim SJ, Schoenberger SD, Thorne JE et al (2015) Topical Nonsteroidal Anti-inflammatory Drugs and Cataract Surgery: A Report by the American Academy of Ophthalmology. Ophthalmology 122(11):2159-2168

14. Wielders LHP, Schouten J, Winkens B et al (2018) European multicenter trial of the prevention of cystoid macular edema after cataract surgery in nondiabetics: ESCRS PREMED study report 1. J Cataract Refract Surg 44(4):429-439

15. Campa C, Salsini G, Perri P (2018) Comparison of the Efficacy of Dexamethasone, Nepafenac, and Bromfenac for Preventing Pseudophakic Cystoid Macular Edema: an Open-label, Prospective, Randomized Controlled Trial. Curr Eye Res 43(3):362-367

16. Moher D, Liberati A, Tetzlaff J et al (2009) Preferred reporting items for systematic reviews and meta-analyses: the PRISMA statement. PLoS Med 6(7):e1000097

17. Higgins JP, Jackson D, Barrett JK et al (2012) Consistency and inconsistency in network meta-analysis: concepts and models for multi-arm studies. Res Synth Methods 3(2):98-110

18. Almeida DR, Johnson D, Hollands $\mathrm{H}$ et al (2008) Effect of prophylactic nonsteroidal antiinflammatory drugs on cystoid macular edema assessed using optical coherence tomography quantification of total macular volume after cataract surgery. $J$ Cataract Refract Surg 34(1):64-69

19. Asano S, Miyake K, Ota I et al (2008) Reducing angiographic cystoid macular edema and blood-aqueous barrier disruption after small-incision phacoemulsification and foldable intraocular lens implantation: multicenter prospective randomized comparison of topical diclofenac $0.1 \%$ and betamethasone 0.1\%. J Cataract Refract Surg 34(1):57-63

20. Cervantes-Coste G, Sanchez-Castro YG, Orozco-Carroll M et al (2009) Inhibition of surgically induced miosis and prevention of postoperative macular edema with nepafenac. Clin Ophthalmol 3:219-226

21. Chatziralli IP, Papazisis L, Sergentanis TN (2011) Ketorolac plus Tobramycin/Dexamethasone versus Tobramycin/Dexamethasone after Uneventful Phacoemulsification Surgery: A Randomized Controlled Trial. Ophthalmologica 225(2):89-94

22. Donnenfeld ED, Perry HD, Wittpenn JR et al (2006) Preoperative ketorolac tromethamine $0.4 \%$ in phacoemulsification outcomes: Pharmacokinetic-response curve. Journal of Cataract Refractive Surgery 32(9):1474-1482

23. Elsawy M, Badawi, Khairy HA. Prophylactic postoperative ketorolac improves outcomes in diabetic patients assigned for cataract surgery. Clinical Ophthalmology. 2013

24. Efficacy of diclofenac eyedrops (1997) in preventing postoperative inflammation and long-term cystoid macular edema. Italian Diclofenac Study Group. J Cataract Refract Surg 23(8):1183-1189

25. Miyake K, Ota I, Maekubo K et al (1999) Latanoprost accelerates disruption of the blood-aqueous barrier and the incidence of angiographic cystoid macular edema in early postoperative pseudophakias. Arch Ophthalmol 117(1):34-40

26. Miyanaga M, Miyai T, Nejima R et al (2009) Effect of bromfenac ophthalmic solution on ocular inflammation following cataract surgery. Acta Ophthalmol 87(3):300-305

27. Miyake K, Nishimura K, Harino S et al (2007) The effect of topical diclofenac on choroidal blood flow in early postoperative pseudophakias with regard to cystoid macular edema formation. Invest Ophthalmol Vis Sci 48(12):5647-5652

28. Miyake K, Ota I, Miyake G et al (2011) Nepafenac $0.1 \%$ versus fluorometholone $0.1 \%$ for preventing cystoid macular edema after cataract surgery. J Cataract Refract Surg 37(9):1581-1588

29. Moschos MM, Chatziralli IP, Pantazis P et al (2012) Is topical diclofenac essential before and after uneventful phacoemulsification cataract surgery? J Ocul Pharmacol Ther 28(4):335-339

30. Pollack A, Staurenghi G, Sager D et al (2017) Prospective randomised clinical trial to evaluate the safety and efficacy of nepafenac $0.1 \%$ treatment for the prevention of macular oedema associated with cataract surgery in patients with diabetic retinopathy. Br $\mathrm{J}$ Ophthalmol 101(4):423-427

31. Rossetti L, Bujtar E, Castoldi D et al (1996) Effectiveness of diclofenac eyedrops in reducing inflammation and the incidence of cystoid macular edema after cataract surgery. Journal of Cataract Refractive Surgery 22:794-799

32. Singh R, Alpern L, Jaffe GJ et al (2012) Evaluation of nepafenac in prevention of macular edema following cataract surgery in patients with diabetic retinopathy. Clin Ophthalmol 6:1259-1269 
33. Singh RP, Lehmann R, Martel J et al (2017) Nepafenac 0.3\% after Cataract Surgery in Patients with Diabetic Retinopathy: Results of 2 Randomized Phase 3 Studies. Ophthalmology 124(6):776-785

34. Ticly FG, Lira RP, Zanetti FR et al (2014) Prophylactic use of ketorolac tromethamine in cataract surgery: a randomized trial. J Ocul Pharmacol Ther 30(6):495-501

35. Tzelikis PF, Morato CS, Neves NT et al (2018) Intraindividual comparison of nepafenac $0.3 \%$ for the prevention of macular edema after phacoemulsification. J Cataract Refract Surg 44(4):440-446

36. Wang Q-w, Yao K, Xu W et al (2013) Bromfenac Sodium 0.1\%, Fluorometholone 0.1\% and Dexamethasone $0.1 \%$ for Control of Ocular Inflammation and Prevention of Cystoid Macular Edema after Phacoemulsification. Ophthalmologica 229(4):187-194

37. Wittpenn JR, Silverstein S, Heier J et al (2008) A randomized, masked comparison of topical ketorolac $0.4 \%$ plus steroid vs steroid alone in low-risk cataract surgery patients. Am J Ophthalmol 146(4):554-560

38. Yavas GF, Ozturk F, Kusbeci T (2007) Preoperative topical indomethacin to prevent pseudophakic cystoid macular edema. J Cataract Refract Surg 33(5):804-807

39. Zaczek A, Artzen D, Laurell CG et al (2014) Nepafenac 0.1\% plus dexamethasone $0.1 \%$ versus dexamethasone alone: effect on macular swelling after cataract surgery. J Cataract Refract Surg 40(9):1498-1505

40. Laursen SB, Erichsen JH, Holm LM et al (2019) Prevention of macular edema in patients with diabetes after cataract surgery. J Cataract Refract Surg 45(6):854-869

41. Duan P, Liu Y, Li J (2017) The comparative efficacy and safety of topical non-steroidal anti-inflammatory drugs for the treatment of anterior chamber inflammation after cataract surgery: a systematic review and network meta-analysis. Graefes Arch Clin Exp Ophthalmol 255(4):639-649

42. Rezar-Dreindl S, Eibenberger K, Pollreisz A et al (2017) Effect of intravitreal dexamethasone implant on intra-ocular cytokines and chemokines in eyes with retinal vein occlusion. Acta Ophthalmol 95(2):e119-e127

\section{Figures}


Pubmed: 3675 Cochrane Library: 6725 Embase: 2248

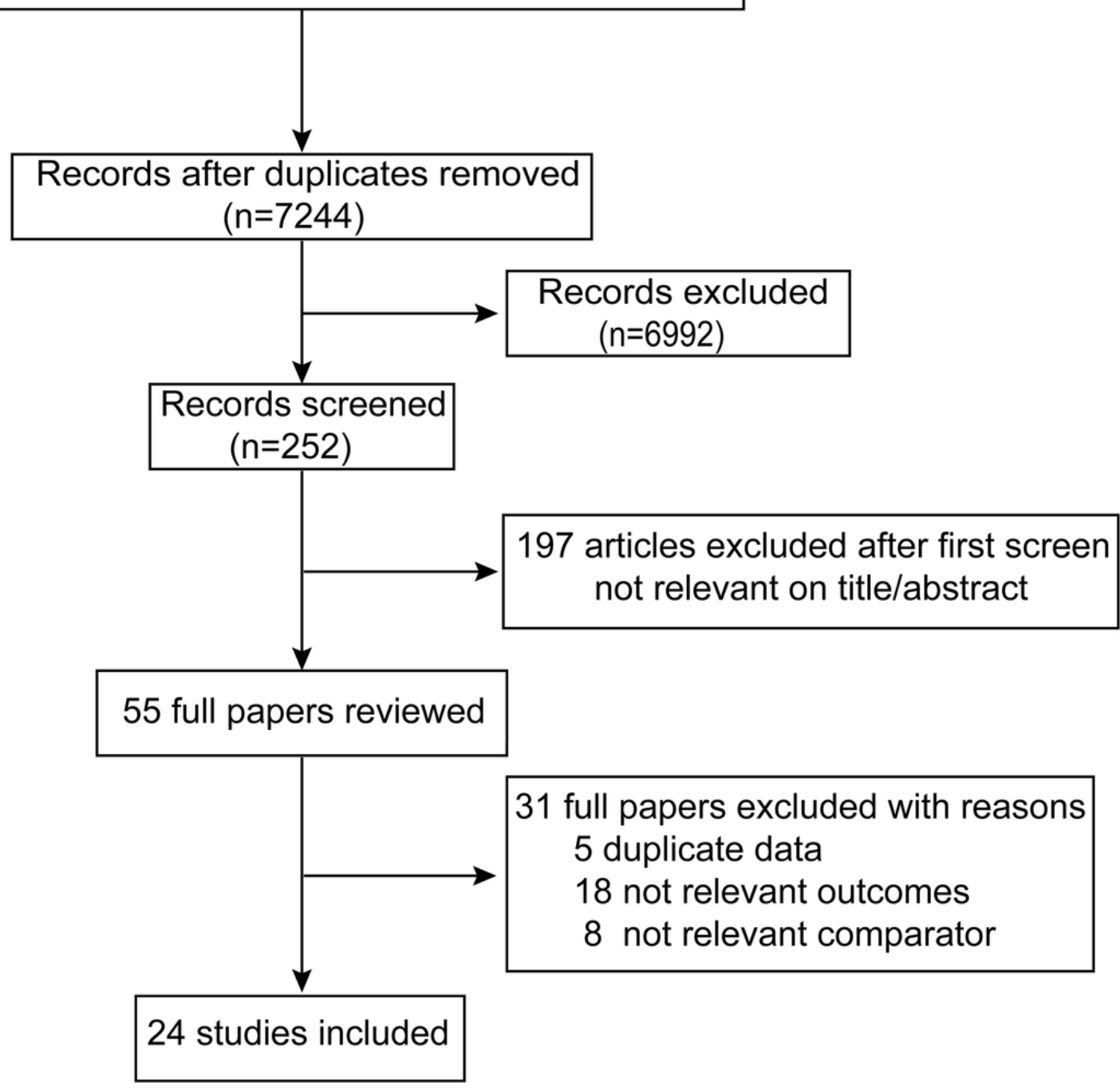

Figure 1

Flow chart of study selection for systematic review and meta-analysis

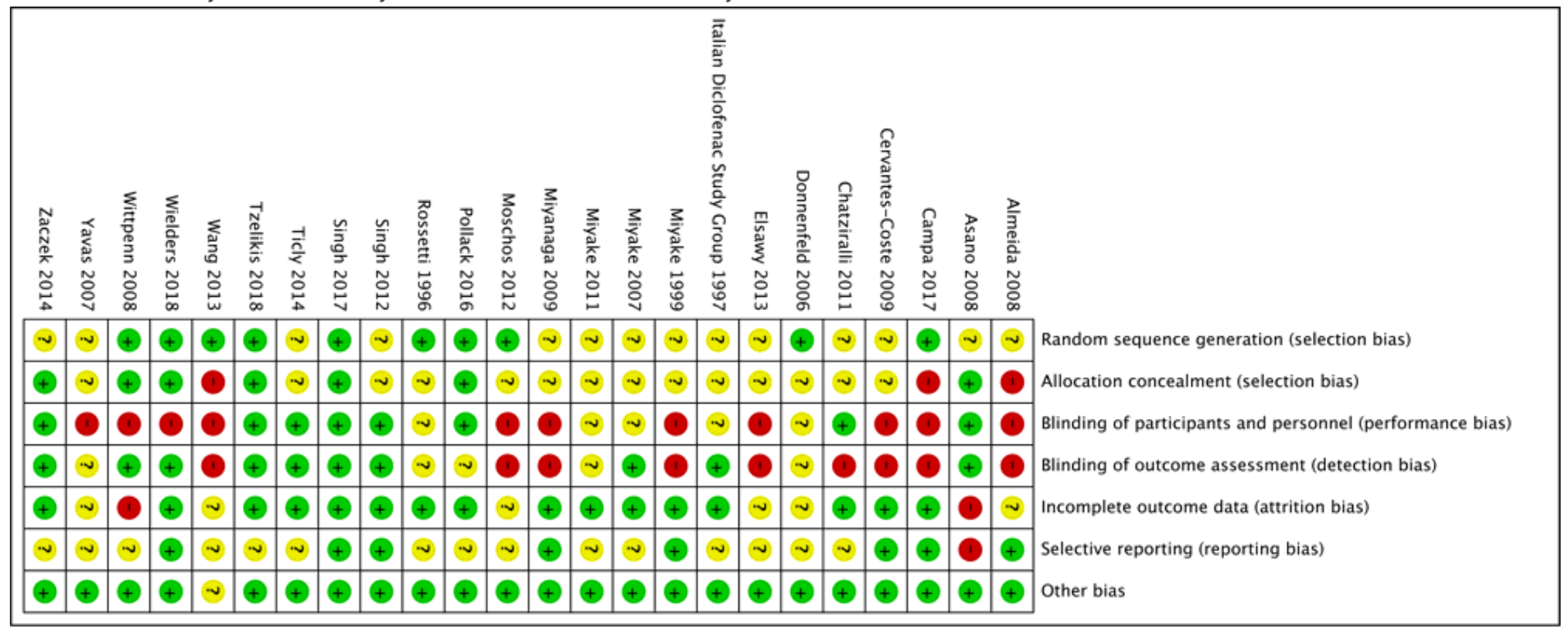

Figure 2 
Risk of bias graph for each study in the network meta-analysis

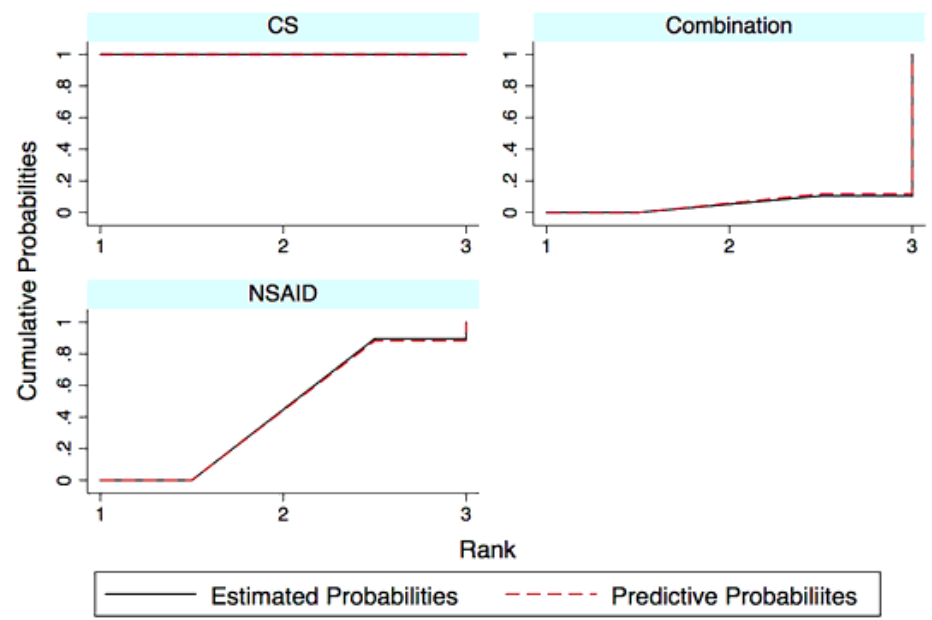

Graphs by Treatment

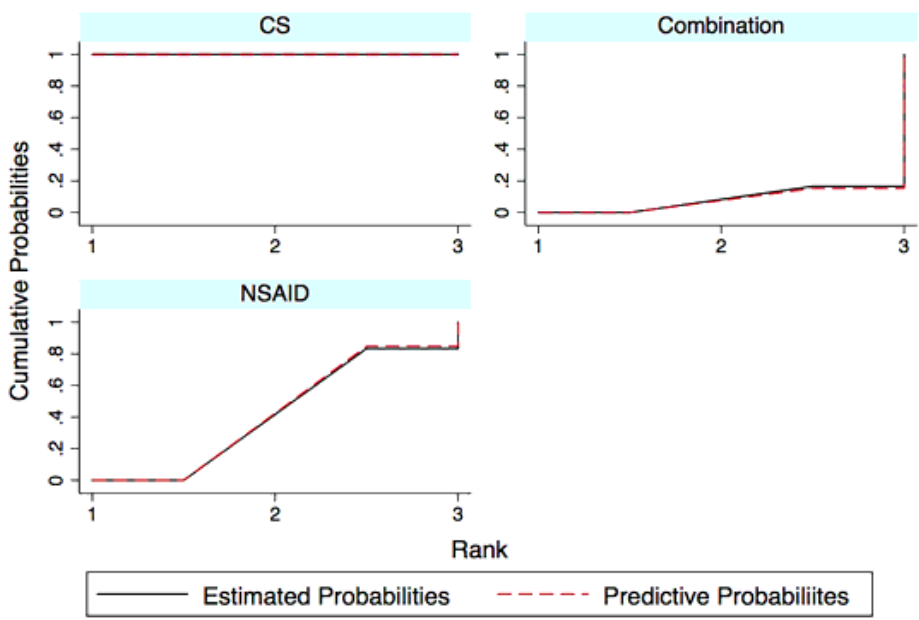

Graphs by Treatment

\section{Figure 3}

Relative rankings of estimated SUCRA values and of probabilities for being the best treatment strategies. CS: corticosteroid, NSAID: non-steroidal anti-inflammatory drugs, CME: cystoid macular edema

\section{a. Network plot of the efficacy of various NSAID and CS}

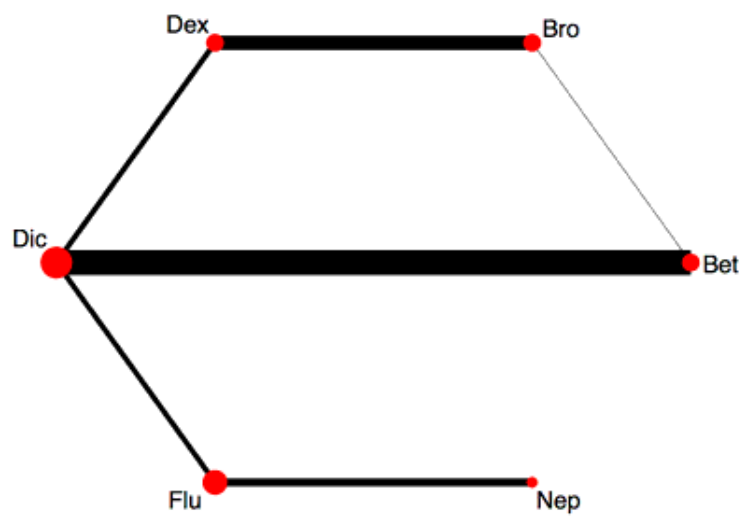

b. Network meta-analysis of the efficacy of various NSAID and CS

\begin{tabular}{|c|c|c|c|c|c|}
\hline Nepafenac & $5.70(2.26,14.38)$ & $0.72(0.17,3.17)$ & $1.95(0.32,12.07)$ & $0.92(0.14,6.30)$ & $2.25(0.47,10.74)$ \\
\hline $0.18(0.07,0.44)$ & Fluorometholone & $0.13(0.04,0.40)$ & $0.34(0.07,1.64)$ & $0.16(0.03,0.87)$ & $0.39(0.11,1.39)$ \\
\hline $1.38(0.32,6.03)$ & $7.87(2.50,24.83)$ & Diclofenac & $2.70(0.93,7.85)$ & $1.28(0.37,4.35)$ & $3.10(1.84,5.23)$ \\
\hline $0.51(0.08,3.16)$ & $2.92(0.61,14.01)$ & $0.37(0.13,1.08)$ & Dexamethasone & $0.47(0.24,0.94)$ & $1.15(0.36,3.68)$ \\
\hline $1.08(0.16,7.36)$ & $6.17(1.15,33.10)$ & $0.78(0.23,2.67)$ & $2.11(1.07,4.19)$ & Bromfenac & $2.43(0.66,8.93)$ \\
\hline $0.45(0.09,2.13)$ & $2.54(0.72,8.97)$ & $0.32(0.19,0.54)$ & $0.87(0.27,2.79)$ & $0.41(0.11,1.51)$ & Betamethasone \\
\hline
\end{tabular}

c. SUCRA ranking of the efficacy of various NSAID and CS
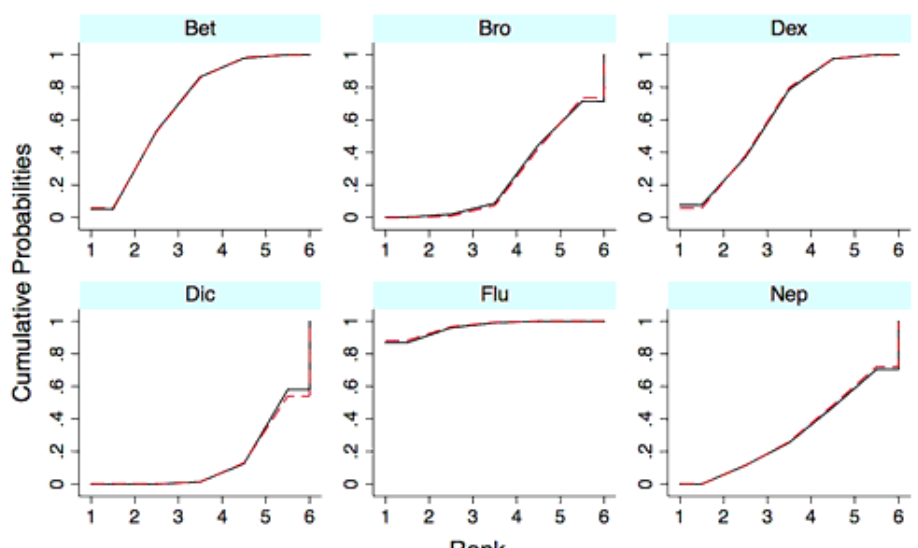

Estimated Probabilities

- - - - Predictive Probabiliites

Graphs by Treatment 
Figure 4

Network meta-analysis of comparisons on different outcomes of treatment incidence of CME after cataract surgery. Bro: bromfenac, Nep: nepafenac, Dic: diclofenac, Bet: betamethasone, Flu: fluorometholone, Dex: dexamethasone

\section{a. CME with non-diabetics}

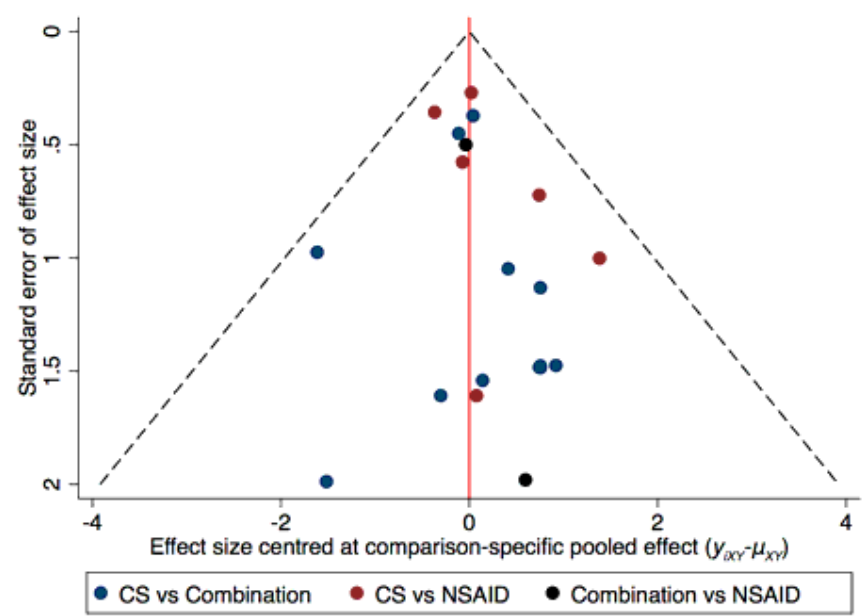

c. CME with mixed populations

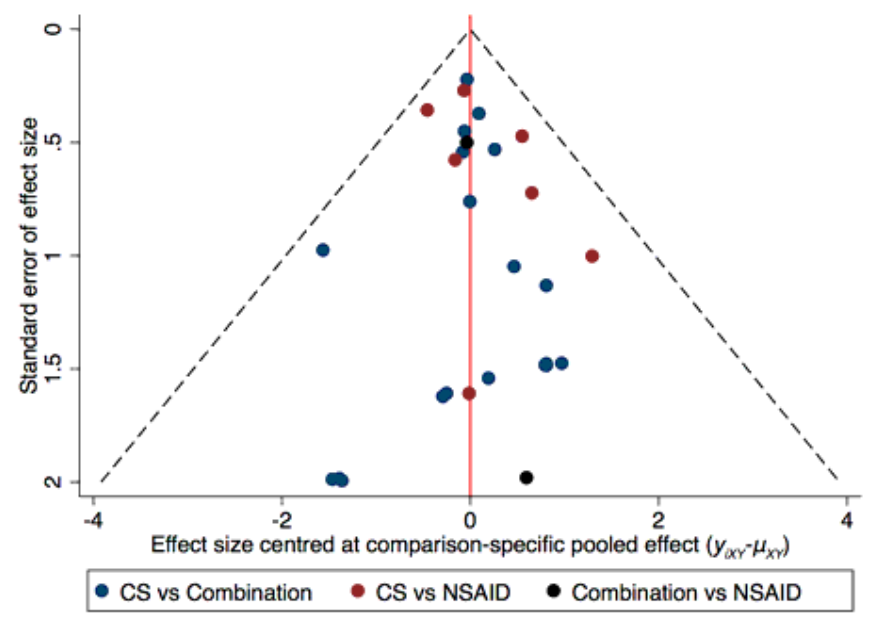

b. CME with diabetics

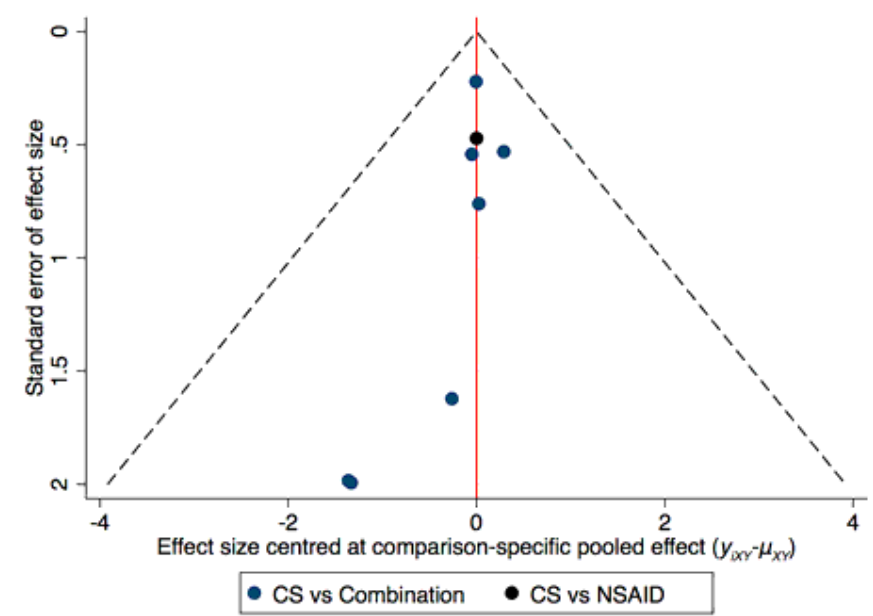

d. CME with different interventions

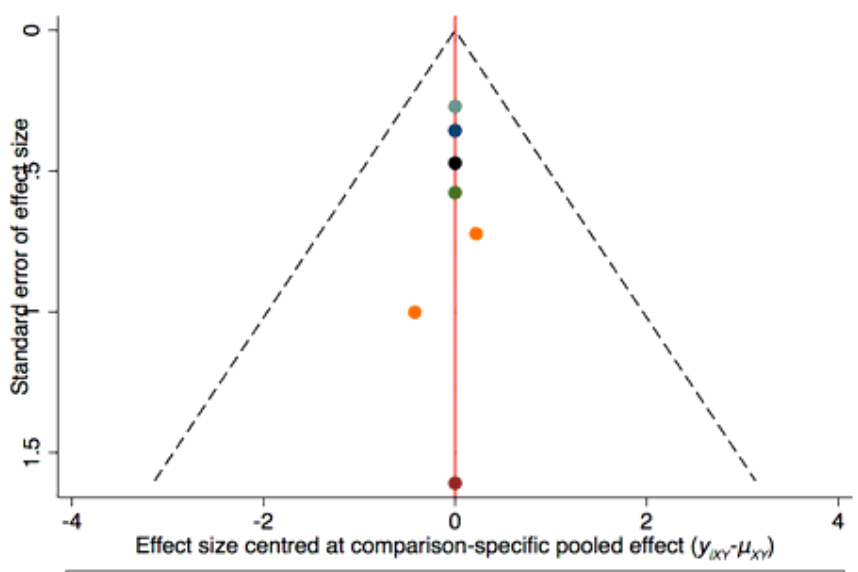

$\bullet$ Bro vs Dex $\bullet$ Bro vs Bet $\bullet$ Dex vs Dic $\bullet$ Dic vs Flu $\bullet$ Dic vs Bet $\bullet$ Flu vs Nep

\section{Figure 5}

Funnel plot of this network meta-analysis. CME: cystoid macular edema, NSAID: non-steroidal anti-inflammatory drugs, Bro: bromfenac, Nep: nepafenac, Dic: diclofenac, Bet: betamethasone, Flu: fluorometholone, Dex: dexamethasone

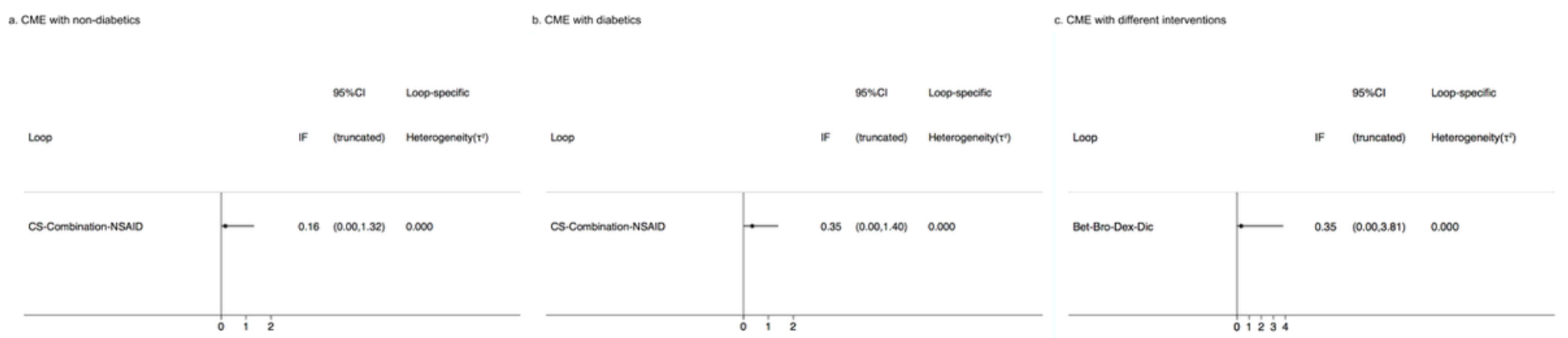

Figure 6

Forest plots of inconsistency in this network meta-analysis. Cl: confidence interval, CME: cystoid macular edema, NSAID: non-steroidal antiinflammatory drugs, Bro: bromfenac, Dic: diclofenac, Bet: betamethasone, Dex: dexamethasone 